\title{
Impact of Political Risk on Frontier Capital Market
}

\author{
Jelena Minovic ${ }^{1}$, Dejan Eric ${ }^{2}$ \\ ${ }^{1}$ Institute of Economic Sciences \\ Zmaj Jovina 12, Belgrade, Serbia \\ E-mail.jelena.minovic@ien.bg.ac.rs \\ ${ }^{2}$ Union University \\ Zmaj Jovina 12, Belgrade, Serbia \\ E-mail.dejan.eric@bba.edu.rs
}

cross $^{r e f}$ http://dx.doi.org/10.5755/j01.ee.27.2.3390

In this paper the impact of political risk on the movement of stock prices in the capital market of the Republic of Serbia is analysed. This is the market with a short history of trading, characterized by a high degree of volatility, with frequent and high jumps in prices. In addition, it is a very narrow and depth lacking market dominated by share trading in that period; the market where the trading in neither treasury, nor corporate bonds was well-developed. All stipulated above indicates a high degree of correlation between the stock price and the current local political events, with the exception of the financial crisis as a global factor. Serbian political shocks are frequent, unpredictable and well defined, which allows us to clearly identify political risk. We have identified the dates/periods when certain jumps in the volatility of the market index return happened, which were then brought into connection with the occurrence of appropriate political news. In that way we were able to quantify the effects of political events on the volatility of return. This is the first paper that deals with the impact of political risk on stock returns in Serbia. Additionally, it is shown that Serbia's score of political risk in December 2009 was the highest in the Eastern Europe region. In 2015 it is around regional Balkan's average, and it lies between Albanian and Macedonian score of political risk index.

Keywords: Political Risk, Belgrade Stock Exchange, Stock Price Volatility, Political Risk Index.

\section{Introduction}

There are many risks associated with investing in emerging capital markets. One of the main risks concerns political situation, which can often be a major obstacle to investment (as suggested in Bekaert et al., 2014; Estrin \& Uvalic, 2013). Since many of these countries have a problem with insufficient levels of domestic savings, they have to take into account that the level of this type of risk is not too high as it might discourage foreign investors. In addition to political risk, in emerging markets additional care has to be taken in terms of other types of risks, such as liquidity risk (see Milunovich \& Minovic, 2014; Minovic \& Zivkovic, 2012), economic risk as well as a whole range of financial risks. Emerging markets, where economic and political environment is still not stable enough, are particularly sensitive to political risk (see Weltman, 2014), which is largely out of the control of the investor. There are cases of extreme political instability, such as wars, terrorism, coups, forced nationalization and similar, that put this kind of risk in the first plan. If we exclude these external examples, there are a number of factors that may enhance or reduce the impact of this risk: frequent changes in regulation, currency instability, high levels of corruption (similar says Liuhto (2010) for Russia, and Wade (2005) for Eastern European countries), weak state institutions, unreformed financial system, differences in legal and regulatory regimes, as well as the restrictive nature of the labour market (Boone, 2007). For investors, political risk means the probability of not achieving the required return, or perhaps even incurring losses due to changes that occur in the government policies of certain countries or their regulatory environment. In contrast to the economic and financial variables, political risk is considerably more difficult to quantify. Theoretically, it is possible to calculate the "results" of political risk or other quantitative indicators, but they are ultimately based on qualitative judgments and analyses (Christy, 2012). These types of risk can be eliminated by avoiding investments in countries with high political risk. In this way, these countries will become less attractive to many potential foreign investors, which make it difficult for external capital rising and may have feedback effect through lower rates of economic growth. On the other hand, if foreign capital comes in such countries, the required rate of return for investors is much higher, so it affects the higher cost of capital. Bekaert et al. (2014) claim that: "Political risk assessment is one of the most important challenges underlying foreign direct investment decisions". On the other hand, Wade (2005) explained that corruption was a major inhibitor to foreign investment in the region of Eastern Europe. Estrin \& Uvalic (2013) explored that “...the unfortunate recent political history of the Balkan region, with conflicts, fragmentation and low growth, have exercised a long lasting and independent effect on their prospects for receipt of foreign direct investment".

Our contribution to the existing literature is twofold:

1. It has been shown which place Serbia occupies in the region of Eastern Europe according to the values of the estimated political risk;

2. It has been shown that political news influence the jumps in volatility of market return index in Serbia. 
This paper lies on the following hypotheses: $i)$ Serbia has a very high level of political risk in the Eastern European region; ii) political risk affects the movement of volatility of stock return in the Republic of Serbia.

In this paper, it has been shown that in 2009 Serbia was ahead according to the level of political risk in the region, and that political risk has decreased in the period 2009-2015. In 2015 the level of political risk in Serbia has been close to regional Balkan's average. Additionally, the impact of political risk on stock prices in the Serbian capital market is analysed in the period 2005-2009. The dates/periods have been identified when relatively unusual jumps in the movement of the market return indices at the Belgrade Stock Exchange (BSE) happened, which are then brought into connection with the occurrence of some political events or the appearance of political news. We measured and studied the effects of the impact of political events on the volatility of returns. Our analysis showed that the Serbian capital market had high degree of volatility and its volatility had high sensitivity on political news.

Apart from the introductory (first section) and the conclusion (seventh section), the paper consists of five parts. A literature review is presented in the second section.

The third section shows position of Serbia in the region of Eastern Europe according to score of political risk. The fourth section presents the data and the methodology. The fifth section contains empirical results, while the analysis of the research results is outlined in the sixth section.

\section{Review of the Literature}

Political risk is a specific type of risk which individual and institutional investors face, as well as companies and even governments or international organizations when investing in a specific country (for detail see Bekaert et al., 2014). As any risk, it is associated with uncertainty that the return which the investor receives is less than expected (Mayo, 2008). Henisz (2002) defines political risks as "risks that are principally the results of forces external to the industry and which involve some sort of government action or occasionally, inaction".

There are papers dealing with the correlation of political risk and capital market returns. Thus, for example, Gemmill (1992) analyses the trends in the share and option market in London in 1987 during the parliamentary elections. Using opinion polls to assess the probability of winning of some political parties he tried to estimate the expected stock return. Diamonte et al. (1996) suggest that political risk is an important determinant of stock return in developing countries, even more than in the developed markets. These authors suggest that the difference between the impact of political risk in emerging economies and developed markets is statistically significant.

There are a significant number of papers in this field concerning the analysis of political risk in individual countries. For example, Chan \& Wei (1996) analyse the impact of political news on stock market volatility in Hong Kong during the period 1990-1993. Hong Kong is an excellent example of high political risk, particularly prior to major political changes and the end of the British governance of the city. Kim \& Mei (2001) also dealt with this issue, who showed that the volatility movement implied the political development of the country. Their results confirm the significant impact of political risk on the volatility and are in accordance with the hypothesis that political development in Hong Kong has a significant impact on its market volatility and returns. The results of both papers have clearly demonstrated that the presence of market jumps can be connected with the appearance of certain political news. The impact of political risk on stock returns volatility on the example of Canada was analysed by Beaulieu et al. (2005). As an example of a significant political risk they stated the possible separation of the province of Quebec from the Canadian federation. Amihud \& Wohl (2004) investigated the extent to which the political events affect market expectations and price changes since the overthrow of Saddam Hussein from power. The authors found that there is a strong connection between the prices of "Saddam contracts" and stock prices, oil prices and exchange rates.

One group of papers analyse the broader aspects of the impact of political risk on macroeconomic developments, investments and operations of international companies. Thus, for example, Jensen (2008) explored how political risk affects the multinational companies operating in emerging markets. He studied the relationship between democratic institutions and flows of foreign direct investments (FDI). He pointed out that the existing studies lack adequate data which prevent collection of indirect evidence on the relationship between political institutions and political risk. Jensen (2008) believes that democratic regimes reduce risks for multinational investors, in particular by increasing the limits of executive power. Howell \& Chaddick (1994) tested projections of political risk methods against actual losses. They focused on how to determine the extent of losses by foreign investors. Clark (1997) developed a model to measure the effects of political risk on the outcome of FDI projects such as the value of the insurance policy which compensates for any losses arising from political events. All model parameters can be evaluated on the basis of current data, which eliminate the difficulty in forecasting future political events. Such political risk is included as a direct cost. Dajcman et al. (2012) investigated the dynamics of stock market return comovements between individual Central and Eastern European countries and developed European stock markets in the period from 1997-2010. They analysed the time-varying dynamics of stock market comovements on a scale-by-scale basis, and they examined how major events (financial crises in the investigated time period and entrance to the European Union) affected the comovement of CEE stock markets with developed European stock markets. A brief review of the literature ends with pointing to the very important paper of Asteriou \& Price (2001) who tested the impact of political instability on economic growth in the UK between 1961 and 1997. They constructed six variables that quantify the political instability and studied their effects on growth. Their results suggest that there is a strong correlation between these variables and growth. Using GARCH-M model they have shown a negative effect of instability on growth and a positive effect on the growth of uncertainty.

Asteriou \& Price (2001) concluded that uncertainty in itself does not affect growth. 
One of the few attempts to analyse the impact of political factors in the Serbian economy is made in the article by Prascevic (2008), who stated more theoretically that there is a correlation between political factors and macroeconomic stability. So far there were no attempts to investigate the impact of political risk on the volatility of stock prices, so that this paper represents a pioneering attempt.

\section{The Position of Serbia According to Score of Political Risk}

Bekaert et al. (2014) introduced a new measure of political risk derived from the yield spread between a country's US dollar debt and an equivalent US Treasury bond. They extracted the part of the sovereign spread that is due to political risk, making use of political risk ratings. They showed that one percent point reduction in the political risk spread is associated with a 12 percent increase in net-inflows of foreign direct investment.

Business Monitor International (BMI, 2015a) calculated short-term political risk index for South East European countries. We plotted BMI's values (see Table 1A in Appendix) on Figure 1, and we can observe that Serbia's short-term political risk score (in March 2015) is 49.8 out of 100.0 (BMI, 2015a). According to BMI Research (2015a) it can be said that countries in the Eastern Europe region suffer of pretty high political risk score. From Figure 1 it can be seen that Serbian score is between Albanian and Macedonian score of political risk index.

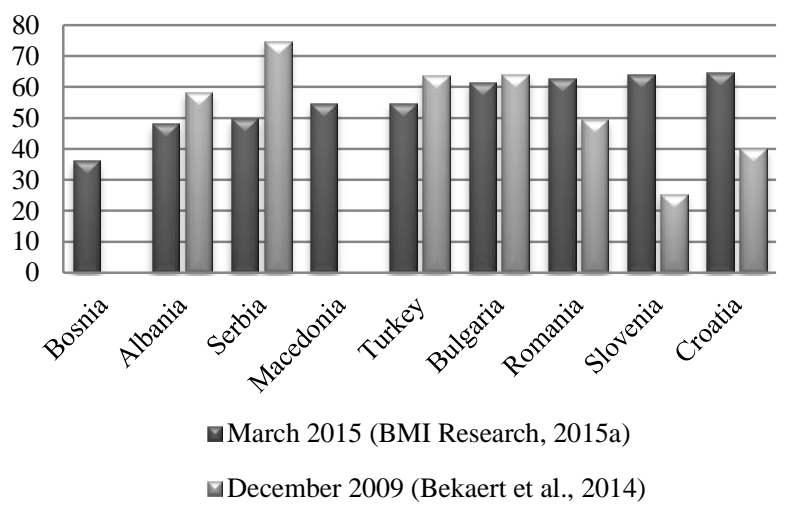

Figure 1. Political risk index and spread Data Source: BMI Research (2015a), Bekaert et al. (2014)

Bekaert et al. (2014) calculated sovereign yield spreads, the extracting political risk spreads, and the absolute political risk spreads for all countries covered by the International Country Risk Guide (ICRG). Erb et al. (1996) suggested that there was considerable information contained in the ICRG composite, financial and economic ratings, in particular. On Figure 1 we plotted only the absolute political risk spreads (APRS) for countries of the Eastern Europe region (see Table 1A in Appendix). According to results of Bekaert et al. (2014), in December 2009, the absolute political risk spread for Serbia is 74.66 basis points which is lower than measured the highest political risk for Somalia at 511.1 basis points. The Serbia's political risk spread lies between Ghana's (74.96 basis points), and Belarus's and India's (74.2 basis points) spreads. The lowest political risk spreads have Taiwan and Namibia at 24.1 basis points (Bekaert et al., 2014). From Figure 1 we can observe that in December 2009 Serbia had the highest political risk spread in the Balkan region. This fact coincides with our analysis from chapter V and VI (political news via stocks volatility).

In December 2009, the Balkan's countries that followed Serbia with high level of political risk spread are Bulgaria, Turkey, Albania, Romania, Croatia and Slovenia. Interestingly, in that period Slovenia had the lowest level of the political risk spread, but in March 2015 situation have been changed, Slovenia's political risk index is on the highest level followed by Croatia's political risk index (see Figure 1).

Bekaert et al. (2014) averaged the spreads across Eastern Europe region, and they found that it is 46.2 basis points. According to their results Serbia's political risk spread (in December 2009) is high relative to value of average Eastern Europe region spread (74.66 versus 46.2 basis points). Thus, hypothesis about the Serbian high score of political risk in the Eastern Europe region cannot be rejected.

According to BMI research from March 2015 (BMI, 2015b) Serbia's short-term political risk index is around regional Eastern Europe's average index (about 55 out of 100). Consequently, overall Serbia's political risk is decreased from 2009 to 2015, according to results by Bekaert et al. (2014), and BMI (2015a). Possible reason for that is that the Serbian Progressive Party (SNS) won half of the votes cast in the March 2014 legislative elections. SNS has 158 seats in the 250 seats single chamber parliament. It is the first time that a political party have a parliamentary majority (Global EDGE, 2014). According to BMI research from February 2016 (BMI, 2016), the Balkans can expect a period of growing instability in 2016. Consequently, the political risk in Serbia will be higher in 2016 than in 2015, due to an early election on April 24, 2016, ongoing tensions in northern Kosovo, a protracted refugee crisis ${ }^{1}$, and the influx of "new" refugees triggered by the war in Syria (for details see BMI, 2016)

Despite declining of political risk in Serbia, Milunovich $\&$ Minovic (2014) showed that Serbia has pretty high level of illiquidity risk in the Balkans region. According to BMI Research $(2015 \mathrm{c}$ ) there are growing risks (see Figure 2) to social and political stability in Serbia. This is due to the slowing of economic growth, impending austerity measures, and persistent tensions with neighbouring Kosovo (BMI Research, 2015c). From Figure 2 we can see that all plotted Risk Indices are relatively high, where the Trade and Investment Risk is the highest (57,7 out of 100,0), according to BMI Research (2015c). Additionally, Global EDGE (2014) found that Serbia suffers from low foreign direct investment (FDI) inflows ( $2 \%$ of GDP), and that the current account deficit in Serbia is among the highest in Eastern Europe.

\footnotetext{
${ }^{1}$ DRC (2016) website: "Serbia, ..., is still hosting the largest displaced population in Europe and it was proclaimed one of 5 countries worldwide affected by a protracted refugee crisis".
} 


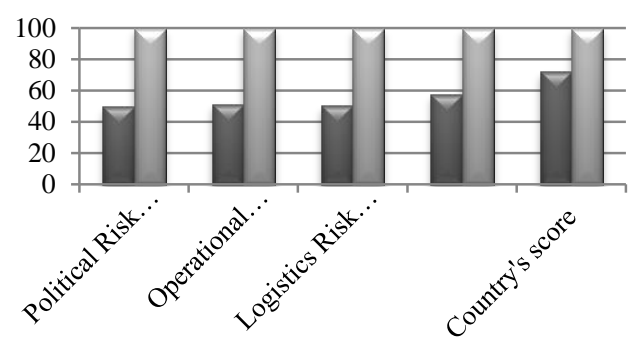

Figure 2. Serbia's Risk Indices in 2015 Data Source: BMI Research (2015a, 2015c)

Weltman (2014) found that: "Estonia, Montenegro, Poland, Romania, Serbia, Slovakia and Slovenia - affected by reduced capital and trade flows, links to Germany and in some cases domestic political upheaval - are all riskier". Estrin \& Uvalic (2013) concluded that "the political risk, deriving from various unsettled political issues in the Balkans region, still seems to exercise a negative effect on foreign direct investment". Global EDGE (2014) expects that Serbia improve state in area of corruption, the judicial system's lack of independence and administrative delays.

\section{Data and Methodology of Volatility Return Measuring}

Volatility of market variables causes uncertainty regarding the future value of a variable. For risk managers it is important to monitor and control the volatility of market variables to assess potential losses (Hull, 2006). Determination of risk is one of the core functions of the financial markets. If the investors decide to invest in a risky asset, they will compare the expected return on assets with the risks it is exposed to. The risk cannot be assessed without measuring time varying conditional variance (volatility) of returns on assets (Engle, 2004), (Minovic \& Zivkovic, 2010). Because of the time dependence of the volatility of return in the shorter time horizons, it is necessary to use in the analysis the model which describes the dynamics of volatility (Schroder \& Schuler, 2003). Such model is Generalized Autoregressive Conditional Heteroscedasticity (GARCH) by Bollerslev (1986).

The subject of observation of events in the capital market of the Republic of Serbia is fluctuation of the BELEXline index ${ }^{2}$, the leading index at the Belgrade Stock Exchange $(\mathrm{BSE})^{3}$. This index ${ }^{4}$ consists of stocks traded on the BSE which met the criteria for the entry in the index basket. No share can have participation in the index greater

\footnotetext{
${ }^{2}$ The BSE calculated and introduced the BELEXline index in April 2007, as a benchmark for monitoring the broader market trends (Minovic \& Zivkovic, 2010)

${ }^{3}$ In December 2005 the BSE created the index called BELEXfm. After some time it was decided, due to changes in market conditions, that this index should be replaced by BELEXline, which would more accurately describe market trends. One of the main reasons that initiated the replacement of the existing index with the new one, is the fact that the enormous increase in stock prices and market activity in general was inadequately represented by the existing indicators of general trends, i.e. by BELEXfm index (http://www.belex.rs/trgovanje/pregled_belexline)

4 The index is weighted by free float market capitalization, it is not adjusted for dividends paid, and is not protected from dilatation effect which occurs due to the payment of dividends (http://www.belex.rs/files/ trgovanje/BELEXline_metodologija.pdf).
}

than a maximum of $10 \%$ in relation to the free-float market capitalization of the index.

In order to test the hypotheses about the instability of return and impact of political events (political risk) on share price changes, and therefore the BELEXline the ARMAGARCH analysis was used. The hypothesis that political risk affects the volatility of returns trends in the Republic of Serbia will not be rejected if the above mentioned series meet GARCH process adequately. In other words, if after the GARCH process specification there is no remaining $\mathrm{ARCH}$ effect in the residuals.

Daily data on the index values are taken from the website of the BSE (www.belex.rs) ${ }^{5}$ for a period of October 4, 2005 to December 31, 2009. The logarithms are calculated on the values of the indices and the daily returns have been found. Daily returns are calculated according to the following formula

$$
R_{t}^{i}=\log \left(P_{t}^{i}\right)-\log \left(P_{t-1}^{i}\right) .
$$

In examining the time series it is very important to examine the properties of the stationarity of the time series, that is, it is important to do the testing for the presence of unit roots in the data. Stationarity properties are important for the ability of prediction (Tsay, 2005). Therefore, for the returns index series the stationarity of the series have been examined $^{6}$ (Table $2 \mathrm{~A}$ in the Appendix). After obtaining the stationary series it was checked if the returns index has a normal distribution using descriptive statistics ${ }^{7}$ (Table 2A in the Appendix). The results of the adequacy of the estimated ARMA model are provided in Table $3 \mathrm{~A}$ in the Appendix.

Starting from the standard methodology of ARMA model testing described in books by Tsay (2005) and Greene (2003), the appropriate ARMA model for BELEXline index return is estimated. After estimation of the ARMA model for BELEXline index return, residuals from the estimated ARMA model are used in order to evaluate one-dimensional GARCH process in order to make adequate assessment of conditional volatility of the series of residuals. For the estimation of GARCH parameters the method of quasi-maximum likelihood is used. Series of logarithmic returns corrected for autocorrelation (residuals) in the expected returns of the market index are calculated by the following equation

$$
r_{t}^{M}=R_{t}^{M}-E_{t-1}\left(R_{t}^{M}\right) \text {. }
$$

Thus, based on the available data, we have tried to identify the volatility of returns which is unstable in time. In order to achieve this, it is first necessary to check whether the return series follows a one-dimensional GARCH process.

Bollerslev (1986) introduced generalized autoregressive conditional heteroscedastic model $(\mathrm{GARCH}) \cdot \operatorname{GARCH}(p, q)$ model is defined as follows $\sigma_{t}^{2}=c+\sum_{i=1}^{q} a_{i} \varepsilon_{t-i}^{2}+\sum_{j=1}^{p} b_{j} \sigma_{t-j}^{2}$,

where $a_{i}, b_{j}$, and $c$ are parameters. Conditional variance is parameterized and depends on $q$ lag of square errors and $p$ lag of conditional variances (Brooks, 2002).

\footnotetext{
${ }^{5}$ http://www.belex.rs/trgovanje/indeksi/belexline/istorijski

${ }^{6}$ Unit root tests are used (i.e. Augmented Dickey-Fuller, ADF test)

7 The coefficient of skewness, the coefficient of kurtosis, and JB test statistics are used
} 
The expected value of a random variable $R_{t}$ is fully described by heteroscedasticity and evaluated by the regression model (Greene, 2003). Stationarity condition of the second degree is as follows

$$
\sum_{i=1}^{q} a_{i}+\sum_{i=1}^{p} b_{i}<1 \text {, (Tsay, 2005; Greene, 2003). }
$$

Johannes (2004) analysed the role of jumping changes in continuous models. His findings showed that such changes have significant statistical and economic role. Author showed that the jumps generate unexpected macroeconomic news, and also investigated what implications those changes have on the valuation of assets. He showed that the jumps have a minor impact on returns, but they are important for pricing interest rate options. Lee \& Mykland (2007) were the first to introduce a new nonparametric test for the detection of statistically significant jumping changes in the prices of assets on a daily basis. These authors have shown that the authenticity of wrong specification of jumps becomes insignificant when using high frequency returns. Lee \& Mykland (2007) applied their test in examining the dynamics of jumps and their distribution in the U.S. capital market. The results they have obtained show that the jumping changes in the prices of individual stocks appear depending on the company's earnings and other news specific to the company.

Todea \& Platon (2012) explored the sudden changes in volatility for the four foreign exchange markets of Central and Eastern Europe. These authors estimated volatility by GARCH(1,1) model and examined the persistence of volatility in the period 1999-2009. Todea \& Platon (2012) identified sudden changes in volatility caused by local financial, economic and political news, with the exception of financial crisis as the global factor.

\section{Research Results}

Applying methodology described in the third part of this paper, the ARMA models have been specified and estimated, having the smallest value of information criteria (AIC and SIC). Therefore, several combinations of $\operatorname{ARMA}(p, q)$ model have been tested, and the minimum value is obtained of AIC and SIC which has $\operatorname{ARMA}(1,3)$ process (all other tested models showed a much worse performance). Consequently, it was discovered that the right model for BELEXline index return is ARMA(1,3)$\operatorname{IGARCH}(1,1)$. That is, we cannot reject the hypothesis that the return of BELEXline follows $\operatorname{ARMA}(1,3)-$ $\operatorname{IGARCH}(1,1)$ process, compared to all other tested competitive models with lower values of information criteria. It is noted that for BELEXline index as indicator of the whole market trend, return meets the so-called Integrated GARCH process (IGARCH). That means that the sum of the estimated ARCH and GARCH coefficients is equal to 1 in the variance equation (see Table $4 \mathrm{~A}$ in Appendix). The economic interpretation of this result is that the volatility of BELEXline returns is persistent.

Table 4A in Appendix shows that all estimated parameters of $\operatorname{ARMA}(1,3)-\operatorname{IGARCH}(1,1)$ process are statistically significant at a confidence level of $1 \%$, except for the constant member in the expected return equation of MA(2) parameters evaluation which are not statistically significant.
Estimated ARMA(1,3)-IGARCH $(1,1)$ model equation for BELEXline have the following form (standard errors of estimated parameters are given in parentheses):

$$
\begin{gathered}
R_{t}=\underset{(0.021)}{0.946} R_{t-1}-\underset{(0.040)}{0.631} \varepsilon_{t-1}-\underset{(0.034)}{0.155} \varepsilon_{t-3}+\varepsilon_{t}, \\
\hat{\sigma}_{t}^{2}=\underset{\left(7.93 \cdot 10^{-8}\right)}{5.42 \cdot 10^{-7}}+\underset{(0.075)}{0.385} \varepsilon_{t-1}^{2}+\underset{(0.043)}{0.655} \sigma_{t-1}^{2} .
\end{gathered}
$$

Adequacy of the specification of the fitted model is checked by using standardized residuals and their squares (Table 1). Conditional standard deviation of BELEXline index return on daily basis is shown in Figure 3.

The results of Ljung-Box statistics (Table 1) of residual and square residual from the GARCH process indicate adequate specification of the evaluated model for describing conditional heteroscedascity of the data. ARCH test has been applied on standardized residuals so as to examine if there is a residual auto-correlation. The values $\mathrm{F}$ and LMstatistics (Table 1) indicate that there is no series correlation of neither fifth nor the tenth degree for BELEXline index return. In order to explore the IGARCH process the Wald test has been applied. The results ${ }^{8}$ of this test (Table 1) show that the BELEXline index returns have unit root in volatility, which means that volatility of this index is persistent in time.

Table 1.

Checking adequacy of the evaluated $\operatorname{ARMA}(1,3)$ $\operatorname{IGARCH}(1,1)$ model

\begin{tabular}{|c|c|c|c|c|c|c|c|}
\hline \multicolumn{3}{|c|}{$\begin{array}{c}\text { The Ljung-Box } \\
\text { statistics }\end{array}$} & \multicolumn{2}{c|}{ ARCH-LM(5) } & \multicolumn{2}{c|}{ ARCH-LM(10) } & $\begin{array}{c}\text { Wald } \\
\text { test }\end{array}$ \\
\hline series & $\mathrm{Q}(36)$ & $\mathrm{Q}^{2}(36)$ & F-stat & Obs $^{2} \mathrm{R}^{2}$ & F-stat & Obs $^{2} \mathrm{R}^{2}$ & F-test \\
\hline \multirow{2}{*}{$\mathbf{R}_{\mathbf{M}, \mathbf{t}}$} & 55.352 & 48.475 & 0.602 & 3.016 & 0.602 & 6.047 & 0.738 \\
& $(0.006)$ & $(0.031)$ & $(0.700)$ & $(0.697)$ & $(0.813)$ & $(0.811)$ & $(0.391)$ \\
\hline
\end{tabular}

Note: $\mathrm{R}_{\mathrm{M}, \mathrm{t}}=\operatorname{dlog}(\mathrm{BELEXline})$; The values of Ljung-Box's statistics are presented for checking heteroscedasticity in residuals and square residuals $\left(\mathrm{Q}\right.$ and $\mathrm{Q}^{2}$ ), and $\mathrm{ARCH}-\mathrm{LM}$ test for checking the residual auto-correlation of the fifth and tenth degree in residuals and Wald test values; $p$-values are given in parentheses.

Source: Authors' estimation

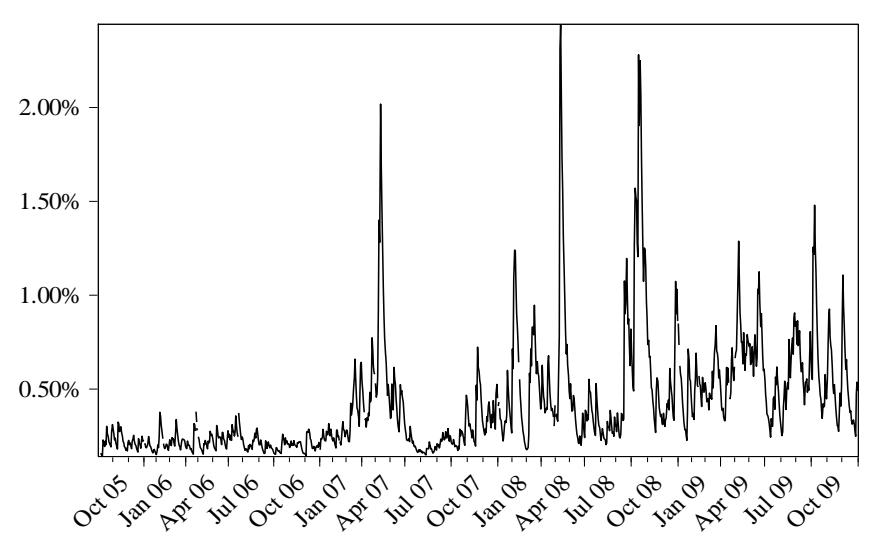

Figure 3. Daily conditional standard deviation of BELEXline index return

Source: Authors' estimation

Based on $F$-statistics and appropriate $p$ values (Table 1) the conclusion can be drawn that the BELEXline index returns volatility equations are correctly estimated. Neither

\footnotetext{
${ }^{8}$ When $p$-value of F-statistics is significantly above $5 \%$ it can be assumed that the zero hypothesis which states that the sum of ARCH and CARCH coefficiens is close to 1 cannot be rejected.
} 
ARCH effect has not remained in residuals after GARCH process specification. Therefore, the hypothesis on instability of return volatility on Serbian market cannot be rejected.

\section{The Main Political Events in Serbia}

The measured average value of the standard deviation in the observed period is $0.42 \%$. Therefore, all the conditional standard deviation values that are in the range of values $(0.42 \%, 1 \%)$ will be considered as significant changes in volatility. Conditional standard deviation values contained in the interval $(1 \%, 2 \%)$ will be considered as a rather high value of volatility (risk), while the value of the standard deviation of more than $2 \%$ is considered extremely high risk.

It was found that political events sometimes generate current (daily) effects on volatility, and sometimes the effect lasts up to a month, when a longer period of increased risk begins (see Table 2).

To understand the political situation in Serbia in the observed period, it is necessary to point out a few events that have a significant impact on the overall orientation of the country. First of all, during that period parliamentary elections were held twice as well as the presidential elections, which largely influenced future political life of the country. There were two paths, bound to the two strongest political options. One was cantered around Democratic Party (Demokratska stranka - DS), which aimed at faster process of integration of Serbia into the European Union. The second was led by the strongest opposition party at that time - Serbian Radical Party (Srpska radikalna stranka - SRS). Their policy was against the European Union and essentially it was an isolation policy. Since both political options were relatively equal in terms of voters support, there was a relatively high level of uncertainty about the political future of Serbia. In addition to three elections, another extremely important political moment was the declaration of independence, proclaimed by the Parliament of Kosovo. According to still positive Constitution of the Republic of Serbia, Kosovo is an integral part of its territory. Such a decision by Pristina, was understood in Belgrade as an act of secession, but with very little room for manoeuvre to prevent it. Namely, it is the fact that since 1999 Kosovo has been under the special regime of international supervision grounded on the 1244 UN resolution.

For most of the period, it can be concluded that it was characterized by high political uncertainty in the country, particularly concerning the formation of a new government and the country's future political course. On the other hand, it should be noted that the capital market in Serbia is still in its infancy, that it has a relatively low level of domestic savings, as well as that most of the action on the BSE resulted from the privatization process. It is well known that the amplitudes of the daily movement of the stock market indices are higher as the market is lacking in depth and that political situation in the country significantly affects index oscillation. Serbian financial market basically lacks depth, which means that there is not a high level of liquidity (Zivkovic \& Minovic, 2010). Foreign investors had a large share in it until the outbreak of the global economic crisis in October 2008 (even $50 \%$ ). Relatively modest responses of several large participants may have a significant impact on prices, and therefore the stock market indices. On the other hand, during that period there was almost no bond market. Only shares were traded on the Belgrade Stock Exchange, which further limited the investors' choices. From January 2008 to September 2009 the decline of the BSE index was more than $60 \%$, and only the indices in Bosnia and Herzegovina decreased more (Eric et al. 2009).

Understanding the background of political developments, we have tried to identify the dates/periods when "unusual" jumps in volatility of market indices occurred, which are then brought into connection with the appearance of appropriate political news and events. In this way, we have attempted to quantify the effects of political events on the volatility of the market index returns.

In Table 2, we have tried to identify the most important events that marked the political life of Serbia in the period.

Key political events ${ }^{9}$ in Serbia in the period $2005-2009$ and their impact on market return volatility

\begin{tabular}{|c|c|c|}
\hline Date & Event/Period/Political News & $\begin{array}{l}\text { Impact } \\
0 / 1 / 2 / 3\end{array}$ \\
\hline May 21, 2006 & Montenegro declared independence and separated from Serbia & 0 \\
\hline Oct 28-29, 2006 & The delay in the functioning of the Assembly for holding a referendum on ratification of the new Constitution & 0 \\
\hline Nov 10,2006 & Beginning of Early elections & 0 \\
\hline Jan 21, 2007 & Early parliamentary elections (the victory of the democratic block) & 0 \\
\hline Feb 1-28, 2007 & $\begin{array}{l}\text { The Serbian Parliament adopted a resolution on Kosovo to reject all suggestions given by the international } \\
\text { mediator Mr Martti Ahtisaari; the International Hague Tribunal rejected the claim of Bosnia and Herzegovina } \\
\text { against Serbia for genocide }\end{array}$ & 0 \\
\hline March 14-21 2007 & The negotiations over the name of the Prime Minister to form a new government & 1 \\
\hline March 28-Apr 4, 2007 & Assembly and its committees are not constituted, the budget is not adopted, the new government is not elected & 1 \\
\hline April 19-May 8, 2007 & Great uncertainty about the post-election agreements & 1 \\
\hline May 8, 2007 & Vice President of the Serbian Radical Party elected the President of the Serbian Assembly & 1 \\
\hline May 13, 2007 & $\begin{array}{l}\text { Vice President of the Serbian Radical Party removed from the position of the President of the Serbian } \\
\text { Assembly }\end{array}$ & 2 \\
\hline
\end{tabular}

\footnotetext{
${ }^{9}$ News taken from: http://www.vesti.rs/arhiva/ (accessed October 2012)
} 


\begin{tabular}{|c|c|c|}
\hline Date & Event/Period/Political News & $\begin{array}{l}\text { Impact } \\
0 / 1 / 2 / 3\end{array}$ \\
\hline May 15, 2007 & New government formed led by the pro-European block & 2 \\
\hline June 5-13, 2007 & $\begin{array}{l}\text { The government announced the adoption of several reform laws, accelerating privatization (the remaining } \\
\text { state-owned enterprises, as well as NIS (Petrol Industry of Serbia) and JAT (Yugoslav Airlines) and much } \\
\text { higher level of coordination with key stakeholders in the global geopolitical scene; President George Bush } \\
\text { announced in Tirana that the U.S. decided that Kosovo should be independent and the message by Kosovo } \\
\text { Albanians summarized in the slogan "independence or war." }\end{array}$ & 1 \\
\hline Oct $30-31,2007$ & $\begin{array}{l}\text { Talks within the ruling coalition - the meetings of party leaders around the date of the election. } \\
\text { Representatives of the major parties - the Democratic Party (DS) and the Democratic Party of Serbia (DSS) } \\
\text { said that provided that there is no agreement on the date of elections, political crisis would prevail in the } \\
\text { country, a crisis of institutions and internal instability. }\end{array}$ & 1 \\
\hline Nov 19-28, 2007 & $\begin{array}{l}\text { The Serbian government has announced to make a decision on the establishment of municipal councils in the } \\
\text { Serbian areas of Kosovo and Metohija in at least three weeks. In this way the idea of a parallel government } \\
\text { would be implemented; Serbia initiated the agreement on admission to the EU. It was announced that on Jan } \\
28 \text { the agreement should be signed }\end{array}$ & 1 \\
\hline Dec 27-31, 2007 & $\begin{array}{l}\text { Serbian Parliament adopted a resolution of the Serbian Parliament on the protection of the sovereignty, } \\
\text { territorial integrity and constitutional order of Serbia, which was proposed by the Government, stating that } \\
\text { international agreements concluded by Serbia, including the Admission Agreement with the European Union, } \\
\text { must function to preserve the sovereignty and territorial integrity; Serbian Parliament adopted Resolution on } \\
\text { Kosovo and Metohija, which, as a priority, defines defending Kosovo as an integral part of Serbia, and all acts } \\
\text { of declaration and recognition of Kosovo's independence, regardless of who adopted and proclaimed them, } \\
\text { will be declared void. It was announced that the local elections in Serbia will be held on } 11 \text { May. Presidential } \\
\text { elections are to be held in January } 2008\end{array}$ & 1 \\
\hline Jan 4, 2008 & $\begin{array}{l}\text { With the enactment of the visa facilitation and readmission, the visas are issued to Serbian citizens in a more } \\
\text { facilitated procedure; the report by the UN Secretary-General Ban Ki-moon said that the main priority of the } \\
\text { Security Council and the international community is to continue to determine the future status of Kosovo. }\end{array}$ & 1 \\
\hline Jan 20,2008 & The first round of presidential elections & 1 \\
\hline Jan 23-25, 2008 & Uncertainty about the victory in the presidential elections & 1 \\
\hline Feb 3, 2008 & The second round of presidential elections & 1 \\
\hline Feb $1-4,2008$ & $\begin{array}{l}\text { The UN Administration in Kosovo accused the government in Belgrade to violate Resolution } 1244 \text { of the UN } \\
\text { Security Council for ordering Serbian minority not to cooperate with the Kosovo institutions; B. Tadic won } \\
\text { the presidential elections; the European Union has adopted 'Joint Action' in a fast written procedure, a } \\
\text { document on the legal and financial basis for sending EU mission to Kosovo }\end{array}$ & 1 \\
\hline Feb 17, 2008 & Kosovo proclaimed independence & 1 \\
\hline $7-28.3 .08$. & $\begin{array}{l}\text { Serbian Government is in crisis over Kosovo, Serbian President announced that, after receiving the decision of } \\
\text { the government, he would call elections in accordance with the constitutional authority, the Government and } \\
\text { the President sent a proposal to dissolve the National Assembly. }\end{array}$ & 1 \\
\hline March 13, 2008 & Parliamentary elections started & 1 \\
\hline April 29, 2008 & Signed Stabilisation and Association Agreement with the European Union & 0 \\
\hline May 9-12, 2008 & $\begin{array}{l}\text { Serbian Government adopted the proposals of the Stabilisation and Association Agreement between Serbia } \\
\text { and Russia in the field of energy. }\end{array}$ & 1 \\
\hline May 11, 2008 & Parliamentary elections (victory of pro-European forces) & 1 \\
\hline May 13-15, 2008 & Negotiations within parties to form a new government & 3 \\
\hline May 22-June 4, 2008 & Uncertainty about forming new government & 1 \\
\hline July 7,2008 & New pro-European government formed & 0 \\
\hline July 9-14, 2008 & $\begin{array}{l}\text { Serbian Government decided to send for ratification the Stabilisation and Association Agreement with the } \\
\text { European Union as well as gas deal with Russia }\end{array}$ & 1 \\
\hline July $23-24,2008$ & Radovan Karadzic arrested and extradited to the Hague & 1 \\
\hline Sep 5, 2008 & Splitting in the Serbian Radical party (leading opposition party, against Serbia's EU integration) & 0 \\
\hline Sep 17,2008 & Two days after Lehman Brothers bankruptcy ${ }^{10}$ & 2 \\
\hline Sep 18-19, 2008 & The first impact of the global financial crisis & 1 \\
\hline Sep 22-23, 2008 & Serbian President required the UN General Assembly to support Serbian resolution on Kosovo & 2 \\
\hline Oct 7-14, 2008 & $\begin{array}{l}\text { The debate and vote in the UN General Assembly on the resolution by which Belgrade requires the Hague } \\
\text { International Court of Justice to give opinion on unilaterally proclaimed independence of Kosovo }\end{array}$ & 2 \\
\hline Oct $15-20,2008$ & Bank panic caused by the impact of global crisis - emptying of the markets and investors leaving ${ }^{11}$ & 3 \\
\hline Oct 21-29, 2008 & $\begin{array}{l}\text { Serbian Progressive Party (SNS) has officially entered the political scene in Serbia, National currency - RSD } \\
\text { mean exchange rate continued a downward trend and reached its lowest value in } 2008\end{array}$ & 2 \\
\hline Feb 6-20, 2009 & Economic crises reached peak in Serbian market ${ }^{12}$ & 1 \\
\hline Oct 5-9, 2009 & $\begin{array}{l}\text { From the annual meeting of the IMF and World Bank in Istanbul comes the news that Russia is likely to grant } \\
\text { Serbia a loan of one billion dollars to finance the budget deficit and infrastructure projects; Negotiations over } \\
\text { Serbia becoming a candidate to join the EU. }\end{array}$ & 2 \\
\hline
\end{tabular}

Note: Value (0) implies there was no significant change in market return volatility under the influence of political issues; Value (1) implies that there were more significant increase in market return volatility due to political issues (i.e. risk up to $1 \%$ ); Value (2) marks there is a rather significant increase in market return volatility due to political issues (i.e. risk is between 1 and $2 \%$ ); Value (3) implies there is an extremely high increase in market return volatility due to political issues (i.e. risk is over $2 \%$ ).

\footnotetext{
${ }^{10}$ Lehman Brothers announced bankruptcy on 15 Sep 2008 but the impact of the global crisis in our market was felt few days later.

${ }^{11}$ See details in Zivkovic \& Minovic (2010).

${ }^{12}$ See details in Zivkovic \& Minovic (2010).
} 
The last quarter of 2006 is characterised by a decreased level of return volatility up to 2007 . One may say this was caused by pre-election events in the Serbian political scene (see Figure 3 and Table 2). Serbian market reached its peak in first months of 2007, when interest for trading at the Belgrade Stock Exchange significantly went up (BSE, 2007). In the beginning of 2007, return volatility was rather low (Figure 3). Republic parliamentary elections were held on January 21, 2007, with democratic block winning ${ }^{13}$, hence volatility did not go up significantly. Serbian Parliament adopted Kosovo Resolution in Feb, 07, rejecting all paragraphs from international mediator Ahtisaari's plan, and the International Hague Tribunal rejected Bosnia and Herzegovina's claim against Serbia for genocide ${ }^{14}$. All the above-mentioned events also had impact on decrease of volatility (risk) in the Serbian market.

Increase in return volatility in the period March-May, 2007 could be brought in connection with political perturbations and problems pertaining to forming a new Serbian Government. In the period between March 14 and May 8, 2007, market index return volatility values were ranging from $0.42 \%$ and $1 \%$, which has been described as a significant change in volatility (see Table 2). In May, 2007, the then Prime Minister V. Kostunica supported appointment of the Serbian Radical Party's (SRS) Vice President T. Nikolic as the Speaker of the Serbian Parliament, which 'cost' Serbia delay of visa reduction negotiations, prices in the stock exchange went down, and RSD currency was weakened. After almost four months of 'bargaining', half an hour prior to the expiry of constitutional deadline, three parties - DSS, DS and G17 plus formed the Government and agreed Nikolic's replacement. President B. Tadic agreed that Kostunica should become new Prime Minister. ${ }^{15} \mathrm{We}$ would like to underscore the period from May 8-12, 2007 when Nikolic, SRS leader was elected the Parliament Speaker for 4 days. In this period, or to be more precise between May 10-18, market index return volatility were ranging from $1 \%$ to 2 $\%$, which implied that there was quite high political risk influence value. In the period between May 21 and June 27, market index return volatility values are lower, ranging from $0.42 \%$ to $1 \%$, which implied significant changes in volatility (see Table 2 ). There were no significant changes in volatility following this period, until October 30, 2007. Significant changes in return volatility took place again in the period between October 30 and Nov 28, 2007, with volatility values ranging from $0.42 \%$ to $1 \%$ (see Table 2 ).

In December, 2007, Contact Group three-party negotiators submitted the UN Security Councils' (SC) report, concluding that Belgrade and Pristina failed to find a common solution regarding Kosovo status. Serbia asked for negotiations to be continued, the parliament adopted resolution beforehand rejecting all possible Kosovo independence related decisions and requires that the UN SC should decide on the status and deployment of a new

\footnotetext{
${ }^{13}$ http://www.blic.rs/Vesti/Politika/25278/Dogadjaji-koji-su-obelezilipoliticku-scenu-Srbije-u-2007

${ }^{14}$ http://www.blic.rs/Vesti/Politika/25278/Dogadjaji-koji-su-obelezilipoliticku-scenu-Srbije-u-2007

${ }^{15}$ http://www.blic.rs/Vesti/Politika/25278/Dogadjaji-koji-su-obelezilipoliticku-scenu-Srbije-u-2007
}

mission. ${ }^{16}$ This period, more precisely from December $21-$ 31 was characterised by significant changes in return volatility and volatility values were ranging from $0.42 \%$ and $1 \%$ (see Table 2). Generally speaking, 2007 was marked by significant events within the European Union, as well as a very dynamic international activity of the Republic of Serbia, mainly focused on meeting conditions for getting closer to the EU and diplomatic activity with regards to status of the southern Serbian province (BSE, 2007).

Some of most important economic events that characterised Serbian economy in the course of 2008 were following: beginning of influence of the global financial crisis, mainly manifested in the last quarter of the year, slowing down of the GDP growth rate, increase of the budget deficit, increase of unemployment, higher indebtedness costs, fall of investment related activities, fall of consumption. Besides, more rigorous regulations dealing with business in financial sector, lower level of trust in international law initiated by taking Kosovo and Metohija territory from the sovereign state, a number of elections, from presidential to all other levels, long (a number of months) negotiations over setting up the new Government, worsened investment rating of the country, frequent local currency exchange rate oscillations in the last annual quester, postponement of privatization and restructuring of big public enterprises.

We would like to emphasise the first quarter of 2008 as a particularly dynamic period when a more significant increase in political risk took place, conditioned by high uncertainty of the presidential elections results in the beginning of the year, followed by crisis caused by proclamation of independence of the Serbian southern province of Kosovo (Feb 17, 2008), fall of the Government, as well as by extraordinary parliamentary elections. Market's reactions to these circumstances were negative and volatile (BSE, 2008). In the period between Jan 4 and Feb 4, 2008, measured return volatility values were ranging from $0.42 \%$ and $1 \%$ - proving a significant increase in political risk. Its influence was even stronger in the period from Feb 5-8 when the values were ranging from $1 \%$ to 2 $\%$ - which was an indicator of a high political risk value (see Table 2).

Market responded in negative and unstable way on all aforementioned events, leading to a fall in index in the first quarter of 2008 by more than $25 \%$, with a loss of more than $17 \%$ only in the course of March (at the time when the Government 'collapsed'), which, until that time, was the biggest monthly loss (BSE, 2008). The USA unanimously acknowledged proclaimed Kosovo independence on Feb 18 , 2008 and announced establishment of diplomatic relations with Pristina. This whole period from Feb 17 to May 11, 2008, was the period of a significant increase of return volatility (risk), since the volatility value was ranging from $0.42 \%$ to $1 \%$ (see Table 2 ).

In the course of March the same year, many EU countries acknowledged Kosovo independence. From January to May, 2008 citizens of Serbia had been voting for three times in only four months (two rounds of presidential

\footnotetext{
${ }^{16}$ http://www.blic.rs/Vesti/Politika/25278/Dogadjaji-koji-su-obelezilipoliticku-scenu-Srbije-u-2007
} 
and parliamentary elections). Since there was no absolute winner in parliamentary elections, in the period from May till July same year, there was a high level of uncertainty with regard to composition of the new Government and general orientation of the country itself. In the course of this period (May-July, 2008) one could perceive the highest peak of the market return volatility in Figure 3. Measured return volatility value in the period from May 13 to 15 , 2008 was over $2 \%$, which marked extremely high level of political risk (see Table 2). In the period from May 22 to June 4 and from July 23-24 2008, return volatility value was in a category of significant risk increase - from $0.42 \%$ to $1 \%$, (see Table 2). Generally speaking, whole 2008 were marked by a high level of political instability, characterised not only by elections, but by various political scandals and imprisonments as well.

Index values in the course of the first half of 2008 were determined by local circumstances, while the second half of 2008 was under influence of events in the world financial market and outset of influences of the global financial crisis and its effects on the Serbian economy. This was particularly visible in the period from mid-September till the end of October, 2008. The last identified peak in Figure 3 (relates to the end of $3^{\text {rd }}$ and beginning of $4^{\text {th }}$ quarter October, 2008) in the market return volatility could be brought into connection with the very outset of the global crisis effects. Concretely speaking, return volatility values in following periods: Sept 17, Sept 22-23, Oct 7-14, were ranging from $1 \%$ to $2 \%$ - proving existence of high risk value. Moreover, in the period between Oct 15 and 20, market return volatility values were over $2 \%$ - extremely high value (see Table 2). Periods: Sept 18-19, Sept 24-Oct 6, Oct 30-Dec 25, Dec 29 and 31, 2008 were periods characterised by significant increase in market return volatility ranging from $0.42 \%$ to $1 \%$. However, periods with high risk values, with volatility values ranging from 1 $\%$ to $2 \%$ are the following: Oct 21-29, Dec 26 and 30, 2008 (see Table 2).

2009 was the last year in our analysis. We measured return volatility value for the following periods: Jan 1-14, Jan 26-30, Feb 6-20, up to May 7, 2009 - which was ranging from $0.42 \%$ to $1 \%$, representing a significant risk increase (see Table 2). There were no marked political events during this period; hence this increase of risk could be put down to effect of the global economic crisis. Figure 3 shows decreased return volatility of the BELEXline index in this period in comparison with the beginning of 2009 (Zivkovic \& Minovic, 2010). However, measured high values of return volatility (risk) ranging from $1 \%$ to $2 \%$ took place in the following periods: May 8-12 and June 1719, 2009. As one of the most important reasons of high risk, we may underline unstable and uncertain situation for Serbs in Kosovo. Besides, we shall point at stronger effects of the global financial crisis. Periods: May 13 -June16, June 22July 3, July 17-28, and Aug 7-Oct 2, 2009 were periods with significant increase in return volatility with values ranging from $0.42 \%$ and $1 \%$ (see Table 2). In the last quarter of 2009, return volatility was noticeable in this period (Figure 3), which pointed at increased market uncertainty. Concretely speaking, periods: Oct 5-9, and Dec 2, 2009 were periods with high risk values, with volatility values ranging from $1 \%$ and $2 \%$. Period from mid -
October to December 1, as well as from Dec 3-14, and Dec 29-31, 2009 were intervals with significant risk increase, with volatility values ranging from $0.42 \%$ and $1 \%$ (see Table 2).

Since our analysis reviewed the period from October 4 until December 31, 2009, our results reiterate that political events had had a significant impact on movements of market return volatility from the second half of 2005 to the second half of 2008 (dynamic international activity of the Republic of Serbia, which was primarily focused on fulfilling prerequisites for accession to the EU, taking of Kosovo territory, presidential, followed by elections at all levels, long negotiations pertaining to forming the Government, etc.). Nonetheless, from the second half of 2008 until the end of 2009, market return volatility was mainly determined by events in the world financial market and effects of the global financial crisis. Analysis of results showed that return volatility of the BELEXline index is persistent in time, which could be perceived in Figure 3 as well. This fact is supported by evidence that the BELEXline index returns, as indicators of the overall market movements, meets the so-called integrated GARCH (IGARCH) process.

\section{Conclusion}

We have measured and studied the effects of the impact of political events on the volatility of returns in the Serbian capital market in the period from 2005 to 2009. This paper is the first to evaluate political risk in the case of Serbia. Serbian political shocks were rather frequent, unpredictable and noticeable in the course of 2008, which enabled us to clearly identify influence of political risk in the Republic of Serbia capital market. There were a number of elections in the course of that year, Kosovo independence was proclaimed, and the first negative consequences of the global financial crisis took place at the end of 2008. It has been proved that market return volatility is persistent for the reviewed period of time. It has been shown that return volatility instability hypothesis in the Serbian market caused by political issues cannot be rejected. Consequently, we found that in December 2009, Serbia had the highest political risk spread among the Eastern European region. It means that hypothesis about the Serbian high score of political risk cannot be rejected. However, in March 2015, the Serbia's political risk index is lower than in 2009, and it lies between Albanian and Macedonian score of political risk index. Additionally, we showed that Serbia's political risk is decreased from 2009 to 2015 , based on results by Bekaert et al. (2014), and BMI (2015a). Despite declining of Serbia's political risk index, it is still high and it is around regional Eastern European average political risk index.

According to BMI Research (2015c) it has been found that the Trade and Investment Risk is the highest in Serbia in 2015. Consequently, this risk is accompanied with high level of political risk (BMI, 2015a), and high level of illiquidity risk (as suggested in Milunovich \& Minovic, 2014; Minovic \& Zivkovic, 2012), is still a major inhibitor to foreign investment in Serbia. The same applies to other countries in the region of Eastern Europe, what coincide 
with findings by Estrin \& Uvalic (2013), and Bekaert et al. (2014).

Reduction of political risk may have a favourable influence on its development from the potential foreign investors' viewpoint as well (as suggested in Bekaert et al., 2014). In order to inflow foreign investments, Serbia is expected to improve conditions in terms of corruption (see
Wade, 2005), the judicial system's lack of independence and administrative delays (as suggested in Global EDGE, 2014). Consequently, stabilisation of political situation, stronger institutions, property protection and stable regulations are factors that may also help development of the capital market in Serbia.

\section{Acknowledgement}

The authors wish to thank Dr. Milos Bozovic for helpful suggestions and valuable comments. All remaining errors are the authors' responsibility. Minovic and Eric acknowledge funding from the Ministry of Education, Science and Technological Development of the Republic of Serbia through research projects 47009 and 179015. The authors thank the anonymous referees for helpful comments.

\section{Appendix}

Table 1A.

The Short Term Political Risk Index and the Absolute Political Risk Spread

\begin{tabular}{|c|c|c|c|c|c|c|c|c|c|c|}
\hline Political Risk Score & Albania & Bosnia & Bulgaria & Croatia & Macedonia & Serbia & Slovenia & Romania & Turkey & Source \\
\hline March 2015 & 48.1 & 36.3 & 61.5 & 64.6 & 54.6 & 49.8 & 64.2 & 62.7 & 54.8 & $\begin{array}{c}\text { BMI Research } \\
(2015 a)\end{array}$ \\
\hline December 2009 & 58.3 & - & 64.2 & 40.1 & - & 74.66 & 25.3 & 49.6 & 63.64 & $\begin{array}{c}\text { Bekaert } \text { et al. } \\
(2014)\end{array}$ \\
\hline
\end{tabular}

Data Source: BMI Research (2015a), Bekaert et al. (2014)

Table 2A.

The results of testing a unit root and descriptive statistics for daily log data and daily log returns of the BELEXline index

\begin{tabular}{|c|c|c|c|c|c|c|c|c|c|c|}
\hline Series & ADF Test & level & Critical Value & $\mathrm{H}_{0}$ & $\mathrm{E}(\mathrm{R})$ & $\boldsymbol{\sigma}$ & $\mathrm{S}$ & $\mathrm{K}$ & $\mathrm{JB}$ & $\mathrm{Prob}$ \\
\hline $\mathrm{p}_{\mathrm{M}, \mathrm{t}}$ & -1.20 & $5 \%$ & -3.41 & $\begin{array}{c}\text { cannot be } \\
\text { rejected }\end{array}$ & 3.35 & 0.21 & -0.15 & 2.02 & 46 & 0.00 \\
\hline $\mathrm{R}_{\mathrm{M}, \mathrm{t}}$ & -20.96 & $5 \%$ & -3.41 & rejected & -0.00 & 0.01 & 0.35 & 12.18 & 3781 & 0.00 \\
\hline
\end{tabular}

Notes: $\mathrm{p}_{\mathrm{M}, \mathrm{t}}=\operatorname{logBELEXline} ; \mathrm{R}_{\mathrm{M}, \mathrm{t}}=\mathrm{d} \log (\mathrm{BELEX}$ line $)$. The null hypothesis $\mathrm{H}_{0}$ : unit root exists in the process; the alternative hypothesis: the process is stationary. $\mathrm{E}(\mathrm{R})=$ Mean; $\boldsymbol{\sigma}=$ Standard Deviation; $\mathrm{S}=$ the coefficient of skewness; $\mathrm{K}=$ the coefficient of kurtosis; JB= the Jarque-Bera test.

Source: Authors' estimation

Table $3 \mathrm{~A}$

Checking adequacy of the estimated ARMA model

\begin{tabular}{|c|c|c|c|c|c|c|c|}
\hline \multicolumn{5}{|c|}{ The Ljung-Box Statistics } & \multicolumn{2}{|c|}{ ARCH-LM(5) test } & \multirow{2}{*}{$\begin{array}{c}\text { The JB Test } \\
\mathrm{JB}\end{array}$} \\
\hline series & $\mathrm{Q}(10)$ & $\mathrm{Q}(36)$ & $\mathrm{Q}^{2}(10)$ & $\mathrm{Q}^{2}(36)$ & F-stat & Obs* $\mathrm{R}^{\wedge} 2$ & \\
\hline $\mathrm{R}_{\mathrm{M}, \mathrm{t}}$ & $\begin{array}{c}6.835 \\
(0.336)\end{array}$ & $\begin{array}{l}46.411 \\
(0.048)\end{array}$ & $\begin{array}{l}278.87 \\
(0.000)\end{array}$ & $\begin{array}{l}313.92 \\
(0.000)\end{array}$ & $\begin{array}{l}37.733 \\
(0.000)\end{array}$ & $\begin{array}{c}161.021 \\
(0.000)\end{array}$ & $\begin{array}{c}4604 \\
(0.000)\end{array}$ \\
\hline
\end{tabular}

Notes: $\mathrm{R}_{\mathrm{M}, \mathrm{t}}=\operatorname{d} \log (\mathrm{BELEXline})$; Results of Q-test statistics (the Ljung-Box statistics) of residual and square residual of logarithm returns in ARMA models. The results of testing of ARCH effect in residuals, as well as JB-test of normality of the residuals obtained from the estimated ARMA models. The number in parentheses denotes $p$-value.

Source: Authors' estimation

Results of specification of GARCH model for BELEXline index

\begin{tabular}{|c|c|c|c|c|}
\hline \multicolumn{5}{|c|}{ Mean Equation } \\
\hline & Coefficient & S. E. & Z-Stat & Prob. \\
\hline $\mathrm{C}$ & 0.0003 & 0.0002 & 1.3931 & 0.1636 \\
\hline $\operatorname{AR}(1)$ & 0.9457 & 0.0211 & 44.9080 & 0.0000 \\
\hline MA(1) & -0.6309 & 0.0395 & -15.9713 & 0.0000 \\
\hline $\operatorname{MA}(2)$ & -0.0276 & 0.0399 & -0.6935 & 0.4880 \\
\hline $\operatorname{MA}(3)$ & -0.1548 & 0.0338 & -4.5822 & 0.0000 \\
\hline \multicolumn{5}{|c|}{ Variance Equation } \\
\hline $\mathrm{C}$ & $5.42 \mathrm{E}-07$ & $7.93 \mathrm{E}-08$ & 6.8308 & 0.0000 \\
\hline $\mathrm{ARCH}(1)$ & 0.3853 & 0.075098 & 5.1305 & 0.0000 \\
\hline GARCH(1) & 0.6545 & 0.043087 & 15.1907 & 0.0000 \\
\hline R-squared & & & & 0.1745 \\
\hline Adjusted R-squared & & & & 0.1690 \\
\hline S.E. of regression & & & & 0.0048 \\
\hline Sum squared resid & & & & 0.0249 \\
\hline Mean dependent var & & & & -0.0002 \\
\hline
\end{tabular}

Source: Authors' estimation 


\section{References}

Amihud, Y., \& Wohl, A. (2004). Political News and Stock Prices: The Case of Saddam Hussein Contracts. Journal of Banking \& Finance, 28(5), 1185-1200. http://dx.doi.org/10.1016/j.jbankfin.2003.08.001

Asteriou, D., \& Price, S. (2001). Political Instability and Economic Growth: UK Time Series Evidence. Scottich Journal of Political Economy, 48(4). http://onlinelibrary.wiley.com/doi/10.1111/1467-9485.00205/pdf.

Beaulieu, M. C., Cosset, J. C., \& Essaddam, N. (2005). The Impact of Political Risk on the Volatility of Stock Returns: The Case of Canada. Journal of International Business Studies, 36(6), 701-718. http://dx.doi.org/10.1057/ palgrave.jibs. 8400160

Bekaert, G., Harvey, C. R., Lundblad, C. T., \& Siegel, S. (2014). Political Risk Spreads. NBER Working Paper No. 19786. Retrieved on October 25, 2015, from http://www.nber.org/papers/w19786.pdf

Bollerslev, T. (1986). Generalized Autoregressive Conditional Heteroscedasticity. Journal of Econometrics, 31, 307-327. http://dx.doi.org/10.1016/0304-4076(86)90063-1

Boone, E. (2007). Political Risk in Emerging Markets. The Rough Notes Magazine, http://www.roughnotes.com/ rnmagazine/2007/october07/10p060.htm (accessed December 2012).

Brooks, C. (2002). Introductory Econometrics for Finance. Cambridge University Press.

BMI Research. (2015a). Business Monitor International. Emerging Europe Monitor, South East Europe, Risk Summary. http://www.emergingeuropemonitor.com/analysis/south-east-europe/political-risk (accessed October 2015).

BMI Research. (2015b). Business Monitor International. Emerging Europe Monitor, Political Risk Analysis - High Risk Of Renewed Instability Despite Breakthrough Deal - NOV 2015, http://www.emergingeuropemonitor.com/political-riskanalysis-high-risk-renewed-instability-despite-breakthrough-deal-nov-2015 (accessed October 2015).

BMI Research. (2015c). Business Monitor International. Serbia Country Risk, http://www.bmiresearch.com/serbia (accessed October 2015).

BMI Research. (2016). Business Monitor International. Emerging Europe Monitor, South East Europe, Political Risk Analysis - Balkans To Face Rising Instability In 2016 - APR 2016, http://www.emergingeuropemonitor.com/politicalrisk-analysis-balkans-face-rising-instability-2016-apr-2016 (accessed March 2016).

BSE. (2007). The Belgrade Stock Exchange Annual Report 2007, http://www.belex.rs/files/proizvodi_i_usluge/Godisnji_ Izvestaj_2007.pdf. (accessed July 2009).

BSE. (2008). The Belgrade Stock Exchange Annual Report 2008, http://www.belex.rs/files/proizvodi_i_usluge/BB_ Godisnji\%20izvestaj\%202008.pdf. (accessed July 2009).

Clark, E. (1997). Valuing political risk. Journal of International Money and Finance, 16(3), 477-490. http://dx.doi.org/10.1016/S0261-5606(97)00008-9

Chan, Y. C., \& Wei, K. C. J. (1996). Political Risk and Stock Prices Volatility: The Case of Honk Kong. Pacific-Basin Finance Journal, 4, 259-275. http://dx.doi.org/10.1016/0927-538X(96)00014-5

Christy, J. (2012). Understanding and Managing Political Risk. About Money, International investing, Global Markets 101: Developed, Emerging \& Frontier Markets, http://internationalinvest.about.com/od/globalmarkets101/a/ countryresearch.htm (accessed December 2012).

Dajcman S., Festic, M. \& Kavkler, A. (2012). Comovement Dynamics between Central and Eastern European and Developed European Stock Markets during European Integration and Amid Financial Crises - A Wavelet Analysis. Inzinerine Ekonomika-Engineering Economics, 23(1), 22-32. http://dx.doi.org/10.5755/j01.ee.23.1.1221

DRC. (2016). Danish Refugee Council. Serbia, Danish Refugee Council Activities in Serbia and Montenegro, https://drc.dk/where-we-work/europe-and-caucasus/serbia (accessed March 2016).

Diamonte, R. L., Liew, J. M., \& Ross, L. S. (1996). Political Risk in Emerging and Developed Markets. Financial Analysts Journal, 52(3), 71-76. http://dx.doi.org/10.2469/faj.v52.n3.1998

Engle, R. F. (2004). Upotreba ARCH/GARCH modela u primenjenoj ekonometriji. Economic Annals, Faculty of Economics, University of Belgrade, 49(162), 339-352. Serbian translation by A. Nojkovic, Journal of Economic Perspectives, (2001), 15, 157-168.

Erb, C. B., Harvey, C. R., \&Viskanta, T. E. (1996). Political Risk, Economic Risk and Financial Risk. Financial Analyst Journal, 52(6), 28-46. http://dx.doi.org/10.2469/faj.v52.n6.2038

Eric, D., Zdravkovic, A., \& Nikolic, D. (2009). Influence of World Crisis on Western Balkans Countries - Undertaken Measures and Expected Effects. Chapter 3 in "Financial System Integration Of Balkan Countries In The European Financial System: Impact Of Global Financial Crisis". University of Nice - Sophia Antipolis, Nice, 17-34.

Estrin, S., \& Uvalic, M. (2013). Foreign direct investment into transition economies: Are the Balkans different?. LSE 'Europe in Question' Discussion Paper Series, No. 64/2013, 5-42.

Gemmill, G. (1992). Political Risk and Market efficiency: Tests based in British stock and options markets in the 1987 election. Journal of Banking and Finance, 16, 211-231. http://dx.doi.org/10.1016/0378-4266(92)90086-F 
Global EDGE. (2014). Serbia: Risk Assessment. Michigan State University. http://globaledge.msu.edu/countries/serbia/ risk (accessed October 2015).

Greene, W. H. (2003). Econometric analysis. $5^{\text {th }}$ edition, Prentice Hall. Upper Saddle River.

Henisz, W. J. (2002). Politics and International Investment. Edward Elgar Publishing Limited, Cheltenham, UK.

Howell, L. D., \& Chaddick, B. (1994). Models of political risk for foreign investment and trade: An assessment of three approaches. Columbia Journal of World Business, 29(3), 70-91. http://dx.doi.org/10.1016/0022-5428(94)90048-5

Hull, J. (2006). Risk Management and Financial Institutitons. Pearson education.

Jensen, N. (2008). Political Risk, Democratic Institutions, and Foreign Direct Investment. Journal of Politics, $70(4), 13$. http://dx.doi.org/10.1017/S0022381608081048

Johannes, M. (2004). The Statistical and Economic Role of Jumps in Continuous-Time Interest Rate Models. Journal of Finance, 59(1), 227-260. http://dx.doi.org/10.1111/j.1540-6321.2004.00632.x

Kim, H. Y., \& Mei, J. P. (2001). What makes the stock market jump? An analysis of political risk on Hong Kong stock returns. Journal of International Money and Finance, 20(7), 1003-1016. http://dx.doi.org/10.1016/S02615606(01)00035-3

Lee, S. S., \& Mykland, P. A. (2007). Jumps in Financial Markets: A New Nonparametric Test and Jump Dynamics. Review of Financial Studies, 00(000), 1-29.

Liuhto, K. (2010). Political Risk for Foreign Firms in Russia. Romanian Journal of Economic Forecasting, 3, $141-157$.

Mayo, H. B. (2008). Introduction to Investments. $10^{\text {th }}$ edition, South-Western Cengage Learning.

Milunovich, G., \& Minovic, J. (2014). Local and global illiquidity effects in the Balkans frontier markets. Applied Economics, 46(31), 3861-3873. http://dx.doi.org/10.1080/00036846.2014.943888

Minovic, J., \& Zivkovic, B. (2010). “Open Issues in Testing Liquidity in Frontier Financial Markets: The Case of Serbia”. Economic Annals, 55(185), 33-62. http://dx.doi.org/10.2298/EKA1085033M

Minovic, J., \& Zivkovic, B. (2012). The impact of liquidity and size premium on equity price formation in Serbia. Economic Annals, 57 (195), 43-78. http://dx.doi.org/10.2298/EKA1295043M

Prascevic, A. (2008). Politicki faktori makroekonomske nestabilnosti u Srbiji. Chapter 3 in M. Zec and B. Cerovic (editors) "Kuda ide Srbija? - osvarenje $i$ dometi reformi". Naucno drustvo ekonomista i Ekonomski fakultet u Beogradu, Belgrade.

Schroder, M., \& Schuler, M. (2003). Systemic Risk in European Banking - Evidence from Bivariate GARCH Models. Discussion Paper No. 03-11, ftp://ftp.zew.de/pub/zew-docs/dp/dp0311.pdf.

Todea, A., \& Platon, D. (2012). Sudden Changes in Volatility in Central and Eastern Europe. Romanian Journal of Economic Forecasting, 15(2), 38-51.

Tsay, R. S. (2005). Analysis of Financial Time Series. Wiley, New Jersey. http://dx.doi.org/10.1002/0471746193

Wade, J. (2005). Political Risk in Eastern Europe. Risk Management Magazine, 52 (3), 24-30. http://cf.rims.org/Magazine/ PrintTemplate.cfm?AID=2645 (accessed October 2015).

Weltman, J. (2014). Looming China crisis adds to eurozone and emerging-market threats - ECR Q3, Euromoney, http://www.euromoney.com/Article/3392195/Looming-China-crisis-adds-to-eurozone-and-emergingmarket.html?copyrightInfo=true (accessed October 2015).

Zivkovic, B., \& Minovic, J. (2010). Illiquidity of Frontier Financial Market: Case of Serbia. Paneconomicus, 57(3), 349367.

The article has been reviewed.

Received in January 2013; accepted in April, 2016. 